\title{
Diploidinių ir tetraploidinių raudonųjų dobilų (Trifolium pratense L.) atsparumas miltligei (Erysiphe trifolii), antraknozei (Kabatiella caulivora) ir rūdims (Uromyces trifolii)
}

\section{Jovita Bukauskaitė,}

Skaidrẻ Supronienė,

Nijolė Lemežienè,

\section{Vida Danytè}

Lietuvos agrariniu ir mišku moksly centras, Instituto al. 1 ,

LT-58344 Akademija, Kédainiu r.

E.paštas: jovita.bukauskaite@lzi.lt
2012-2013 m. Lietuvos agrarinių ir miškų mokslų centre, Žemdirbystės instituto žolių selekcijos sẻjomainoje, buvo tiriamos 84 raudonųjų dobilų ịvairios kilmès veislių, selekcinių linijų ir laukinių ar pusiau laukinių ekotipų atsparumas grybinèms ligoms. Tyrimas atliktas lauko sąlygomis esant natūraliai miltligès (Erysiphe trifolii), antraknozès (Kabatiella caulivora) ir rūdžiu (Uromyces trifolii) infekcijai. Ištyrus veisles ir selekcines linijas, nustatyta, kad pagal ploidiškumą antraknozei atspariausios diploidinès selekcinès linijos 2091, 2106, 2088, tetraploidinès - 2281, 2293 ir veislès 'Vulkan', 'Divaja,' 'Sadūnai'; jautriausia diploidinè selekcinè linija - 2093 ir tetraploidinè veislè - 'Varte.' Miltligè raudonųjų dobilų veislèse ir selekcinèse linijose išplito tik sëjos metais (2012), o rūdys - tik antraisiais - $2013 \mathrm{~m}$. Miltligè ir rūdys pagal ploidiškumą labiau pažeidžia diploidinius dobilus nei tetraploidinius. Ligos nespèjo smarkiai pažeisti žolinio pasèlio, nes buvo pjaunama žolè. Tačiau sẻkliniame pasẻlyje ligos plito iki visiškos augalo brandos, buvo didesnis ligų intensyvumas.

Raktažodžiai: Trifolium pratense, Erysiphe trifolii, Kabatiella caulivora, Uromyces trifolii, atsparumas

\section{IVADAS}

Raudonieji dobilai (T. pratense) - labai svarbi pašarinè, ankštinè žole daugelyje pasaulio šalių. Viena iš kliūčiu efektyviai auginti raudonuosius dobilus - jautrumas ịvairioms ligoms. Žymius derliaus nuostolius ir pasèlių išretejimą kelia šaknų puviniai, o lapų ir stiebų ligos kelia didesnę žalą sèkliniams pasèliams. Atsparumas ligų patogenams yra svarbi savybė vykdant dobilų, taip pat ir kitų augalų, selekciją (Gaue, Ingwersen, 2003; Pokorny et al., 2003), todèl selekcionuojant dobilus daugelyje pasaulio šalių ypač didelis demesys kreipiamas $i$ atsparumą ligoms. Itvairiose šalyse tiriamas atsparumas dobilų vėžiui Sclerotinia trifoliorum Eriks. bei antraknozei - dobilų deguliams (Colletotrichum trifolii Bain. ir Kabatiella caulivora
Kirchn.) (Janossy, 1971; Smith et al., 1993; Svirskis, 1995; Onberg et al., 2008). Lietuvoje tai viena iš pagrindinių priežasčių, dèl ko šio augalo pasèliai yra trumpaamžiai (Gaurilčikienė, 1992). Pasaulyje sukurta veislių, kurios išlieka produktyvios 3-4 metus (Gaue, Ingwerasen, 2003; Öhberg et al., 2005; Taylor, 2008). Nera aiškios nuomonès apie diploidinių ir tetraploidinių dobilų skirtumus. Žemdirbystès institute darytų tyrimų duomenimis, tetraploidinių raudonųjų dobilų sausos masès derlius buvo didesnis, tačiau sèklų daugiau prikulta iš diploidinių dobilų (Liatukas, Bukauskaite, 2012). Tai nurodo ir kiti autoriai, aiškindami mažesnị tetraploidinių dobilų sèklų derlių tuo, kad bitèms juos sunkiau apdulkinti. Nemažai autorių teigia, kad tetraploidiniai dobilai atsparesni ligoms, tačiau yra ir priešingų nuomonių (Taylor, 1996). 
Dobilų deguliai, arba antraknozė (K. caulivora), yra viena iš žalingiausių raudonųjų dobilų antžeminès dalies ligų Šiaurès Amerikoje, Australijoje, Europoje, Šiaurès Afrikoje, Azijoje (Gaurilčikienè, 1992; Bayliss et al., 2002; Repšienè, Skuodienè, 2006; Hua et al., 2009). Dobilų antraknozès simptomai dažniausiai pasirodo butonizacijos tarpsniu ir plinta iki vegetacijos pabaigos, tačiau gali pažeisti visas antžemines augalo dalis bet kuriuo augalo augimo tarpsniu. Ligos pažeisti stiebai ir lapkočiai išlinksta, susisuka, lapai ir žiedai nusvyra, nuruduoja, atrodo lyg nudeginti. Liga itin žalinga - labai sumažeja sèklų derlius arba augalai visai žūsta (Gaurilčikienè, Staniulis, 2006). K. L. Bayliss ir kt. (2001) nurodo, kad antraknozei intensyviai vystantis galimi $50 \%$ šieno ir $90 \%$ sèklų (šiai ligai jautrių veislių) nuostoliai. Vienas iš būdų kontroliuoti šią ligą - atsparių veislių auginimas (Bayliss et al., 2002).

Pakankamai žalingos ir kitos lapu dèmètligès bei miltligè (sukèlèjas - Erysiphe trifolii) (Repšienè, Skuodienè, 2006). Miltligè - žalinga lapų liga, padaranti dobilams daug nuostolių (Pakorny et al., 2003). JAV ji traktuojama kaip žalingiausia dobilų liga (Kentuky Pest News, 2003). Ši liga pažeidžia dobilų ir kitų ankštinių žolių lapus, rečiau stiebus. Ant pažeistų augalų lapų viršutinès pusès susiformuoja tankus baltas grybienos apnašas. Ši liga pablogina šieno kokybę. Jeigu miltligè plinta labai smarkiai, pažeisti lapai pagelsta ir nukrenta, galimi šieno arba sẻklų derliaus nuostoliai (Kentuky Pest News, 2003; Gaurilčikiene, Staniulis, 2006).

Dobilų rūdys (sukèlejas - Uromyces trifolii) daugelyje pasaulio šalių dobilams pridaro didelių nuostoliu (Inch et al., 1993; Rizvi et al., 1993). Vasarą ant augalų lapų, dažniausiai apatinejje pusejje, pasirodo rudi spuogeliai - urèdžiai. Ant dobilų jie - labai smulkūs, šviesiai rudi. Vèliau urèdžius pakeičia juodi teliai, formuojantys teliosporas, kuriose grybas žiemoja (Gaurilčikienè, Staniulis, 2006). Rūdys smarkiau išplinta antroje vasaros puseje, todèl šienaujamuose žolynuose didesnès žalos nepadaro (Rizvi et al., 1993). Rūdys blogina pašarų kokybę, jeigu vèluojama nuimti derlių (Inch et al., 1993).

Antžeminès dalies ligos tiesiogiai pasèlio retejjimui įtakos neturi, tačiau gali pabloginti augalų pasiruošimą žiemai. Augalai taip pat lengviau užsikrečia bei tampa jautresni šaknų ir pašaknio ligų sukėlejams. Tai įvyksta, kai lapai stipriai pa- žeidžiami dèmètligèmis, miltlige ar rūdimis, tada augalas šaknyse sukaupia mažiau maisto medžiagų (Taylor, 1996; 2008). Lapų ir stiebų ligų kompleksas pablogina pašaro kokybę, lètina augalų atžèlimą po pjūčių bei gali stipriai sumažinti ar net visiškai sunaikinti sèklų derlių. Raudonujuc dobilų sèklininkystè dèl nepakankamo veislių atsparumo ligoms (kartu su kitais nepalankiais veiksniais) yra rizikinga bei gana nepelninga žemès ùkio augalų sèklininkystès sritis (Boller, 2010). Atsparumo selekciją komplikuoja tai, kad raudonieji dobilai yra kryžmadulkiai. Šio tipo augalams grižtamoji selekcija, kai kiekvienos kartos atrenkami atspariausi augalai, vèliau tarpusavyje kryžminami, yra efektyvi kuriant atsparias veisles. Dabartiniu metu Europoje raudonųjų dobilų selekcija yra mažiau intensyvi, todèl tinkamų atsparumo donorų taip pat yra mažiau (Xie et al., 1997; Gaue, Ingwerasen, 2003; Pokorny et al., 2003; Okumura, 2005; Taylor, 2008).

Tyrimo tikslas - nustatyti diploidinio ir tetraploidinio raudonojo dobilo (T. pratense) genetinès kolekcijos atsparumą antžeminès dalies ligoms - antraknozei ( $K$. caulivora), miltligei (E. trifolii) ir rūdims (U. trifolii).

\section{METODAI IR SĄLYGOS}

2012-2013 m. sëjos genetinèje kolekcijoje buvo tiriamos diploidinių (43) ir tetraploidinių (41) raudonųjų dobilų ịvairios kilmès veislès (44), selekcines linijos (37) ir laukiniai (2) ar pusiau laukiniai ekotipai (1). Tyrimas atliktas lauko sąlygomis esant natūraliai grybinių ligų infekcijai.

Raudonųjų dobilų genetiné kolekcija buvo irrengta Lietuvos agrarinių ir miškų mokslų centre, Žemdirbystès instituto žolių selekcijos laukuose, giliau karbonatiniame, sekliau glejjiškame vidutinio sunkumo priemolio rudžemyje (Endocalcari - Epihypogleyic Cambisol RDg8 - k2). Armuo 25-30 cm, kurio $\mathrm{pH}-7,2-7,5$, humuso 2,0-2,46 \%. Prieš kultivavimą išbertos fosforo $\left(\mathrm{P}_{60}\right)$ ir kalio $\left(\mathrm{K}_{90}\right)$ trąšos, prieš dobilų sèją - išlyginta dirva. Kolekcija pasèta birželio $8 \mathrm{~d}$. rankine sejjamąja „Winterstager“. Tos pačios veislès, selekcinès linijos, laukiniai ar pusiau laukiniai ekotipai buvo sèjami įrengiant žolinę ir sèklinę kolekciją. Raudonieji dobilai sèti 3 pakartojimais, skarifikuotomis sèklomis (švitriniu popieriumi) po 2 eilutes, kurių ilgis $-5 \mathrm{~m}$., atstumas tarp numerio 
eilučių - 0,5 m., atstumas tarp skirtingų numeriu $-1 \mathrm{~m}$. Tarpueiliai purkšti glifosatais rankiniu purkštuvu.

$2012 \mathrm{~m}$. miltligès intensyvumas buvo vertintas 3 kartus kas 3 savaites (I apskaita rugsèjo $10 \mathrm{~d}$. (29 BBCH), II - rugsèjo $28 \mathrm{~d}$. (49 BBCH), III - spalio 19 d. (61 BBCH)), o antraknozès intensyvumas vertintas 2 kartus (I apskaita - rugséjo $28 \mathrm{~d}$. (49 $\mathrm{BBCH})$, II - spalio 19 d. (61 $\mathrm{BBCH})$. $2013 \mathrm{~m}$. sèkliniame pasèlyje antraknozès intensyvumas vertintas kas 2 savaites, atliktos 4 apskaitos (I apskaita - birželio 10 d. (65 BBCH), II - birželio $24 \mathrm{~d}$. (69 BBCH), III - liepos 8 d. (72 BBCH), IV - liepos 22 d. (80 BBCH)). Žoliniame pasèlyje antraknozè pradèjo plisti prieš II pjūti, atliktos 2 apskaitos (I apskaita - liepos 15 d. (51 BBCH), II - liepos 29 d. (69 BBCH)). Rūdys sèkliniame pasèlyje vertintos kas 2 savaites, atliktos 5 apskaitos (I apskaita - gegužès 27 d. (51 BBCH), II - birželio $10 \mathrm{~d}$. (65 BBCH), III - birželio $24 \mathrm{~d}$. (69 BBCH), IV - liepos 8 d. (72 BBCH), V - liepos 22 d. (80 BBCH)). Žoliniame pasèlyje atliktos 2 apskaitos prieš I (I apskaita - gegužès $27 \mathrm{~d}$. (51 $\mathrm{BBCH})$, II - birželio $10 \mathrm{~d}$. $(65 \mathrm{BBCH}))$ ir II pjūtis (I apskaita - liepos 15 d. (51 BBCH), II - liepos 29 d. (65 BBCH)). Sèklinis pasèlis nukultas rugpjūčio $7 \mathrm{~d}$. Augalų augimo tarpsniai nustatyti pagal BBCH skalę (Meier, 2001). Ligų (miltligé, antraknozè, rūdys) intensyvumas vertintas 1-9 balu sistema: 1 balas - $0 \%, 2$ balai - 0,1\%, 3 balai - $1 \%$, 4 balai $-5 \%, 5$ balai - $10 \%, 6$ balai - 20\%, 7 balai $-40 \%, 8$ balai - $60 \%$, 9 balai - $80 \%$ ligos intensyvumo. Balu sistema pasirenkama dèl greitesnio vertinimo bei iš esmès panašaus tikslumo kaip ir naudojant procentines vertinimo skales (Hartleb et al., 1997; Hartung, Piepho, 2007; Poland, Nelson, 2011). Iš kiekvieno laukelio buvo ívertinta (balais) po 10 augalų ir išvestas bendras vidurkis. Sèklinio ir žolinio pasèlio vertinimo sistema buvo vienoda.

Ligos progresas sezono metu (AUDPC) apskaičiuotas pagal formulę:

$$
\mathrm{AUDPC}=\sum_{i=1}^{n-1}\left[\left(t_{i+1}-t_{i}\right)\left(y_{i}+y_{i+1}\right) / 2\right]
$$

$t$ - laikotarpis tarp apskaitų dienomis;

$y$ - ligos intensyvumas kiekvienos apskaitos metu;

$n$ - vertinimo skaičius (Campbell, Madden, 1990).
Tyrimų duomenys apdoroti dispersinès analizès metodu (Tarakanovas, Raudonius, 2003).

\section{REZULTATAI}

$2012 \mathrm{~m}$. vasara buvo vidutiniškai šilta, lietinga ir vejuota. Pasireiške dideli temperatūrų skirtumai ir svyravimai tarp dekadų. Vèsesnis ir sausesnis buvo birželis, o šiltesnè ir lietingesnè - liepa. HTK sudarè 1,8 (norma 1,4). Produktyvios drègmès atsargos žemès ūkio augalams buvo pakankamos. Šiluma ir drègmè skatino raudonųjų dobilų grybinių ligu vystymąsi bei plitimą. Ruduo buvo šiltas, lietingas, vejjuotas ir ilgas. Šiltesnis ir lietingesnis buvo lapkritis, o sausesnis - rugsèjis. Vidutinè rudens mènesių oro temperatūra buvo $1,4{ }^{\circ} \mathrm{C}$ aukštesnè už daugiameti vidurkį, o kritulių iškrito $132 \%$ daugiamečio vidurkio. Spalio $26 \mathrm{~d}$. atvėsus orams baigèsi daugiamečiu žolių vegetacija.

2013 m. pavasaris buvo trumpas, jau gegužès pirmojo dešimtadienio pabaigoje ji pakeitè vasariškai šilti orai. Daugiamečių žolių vegetacija prasidèjo balandžio 18-20 d. staiga atšilus orams ir paros vidutinei temperatūrai viršijus $5{ }^{\circ} \mathrm{C}$ (apie savaitę vèliau už daugiamečius vidurkius). Daugiametèms žolėms pavasaris buvo itin palankus. Dèl šiltų orų greitai augo ir brendo daugiametès žolès. Drègmès trūkumas augalų pasèliams buvo pastebimas iki liepos antrojo dešimtadienio. Labiausiai augalams drègmès trūko pirmojo liepos dešimtadienio pabaigoje. Šiluma ir antros birželio bei liepos mènesio pusés drègmé paspartino augalų augimą, kartu ir grybinių ligų vystymąsi.

Raudonụjų dobilų genetinių išteklių kolekcijoje antraknoze išplito abejais tyrimų metais, tačiau jos intensyvumas smarkiai skyrèsi. Antraknozès pažeistų lapų plotas sezono metu (AUDPC) diploidinių ir tetraploidinių veislių bei selekcinèse linijose buvo labai panašus (2 lentelè). $2012 \mathrm{~m}$. diploidinių ir tetraploidinių dobilų sèklinio pasèlio vidutinis lapu ploto pažeidimas buvo beveik toks pat: diploidinių - 182,7, o tetraploidinių - 183,4; $2013 \mathrm{~m}$. atitinkamai - 461,7 ir 405,4. Sèjos metu žoliniame pasèlyje antraknozės pažeidimai buvo šiek tiek mažesni nei sèkliniame. Ligos pažeistų diploidinių dobilų lapų plotas vidutiniškai buvo 155,6 , o tetraploidinių - 131,4. $2013 \mathrm{~m}$. žoliniame pasèlyje liga nespejo išplisti, nes buvo nupjauta žolè. Diploidinių ir tetraploidinių raudonųjų dobilų pažeistų lapų plotas sezono metu (AUDPC) sieke vidutiniškai 38. 
1 lentelè. Meteorologinès sąlygos, Dotnuva, 2012-2013 m.

Table 1. Meteorological conditions, Dotnuva, 2012-2013

\begin{tabular}{|c|c|c|c|c|c|c|c|c|c|c|}
\hline \multirow{4}{*}{$\begin{array}{l}\text { Mènuo } \\
\text { Month }\end{array}$} & \multicolumn{5}{|c|}{ Temperatūra / Temperature ${ }^{\circ} \mathrm{C}$} & \multicolumn{5}{|c|}{ Krituliai / Precipitation $\mathrm{mm}$} \\
\hline & \multicolumn{4}{|c|}{$\begin{array}{c}\text { Vidutinè } \\
\text { Mean }\end{array}$} & \multirow{3}{*}{$\begin{array}{c}\text { 1924-2012- } \\
2013 \mathrm{~m} . \\
\text { vidurkis } \\
1924-2012- \\
2013 \text { Mean }\end{array}$} & \multicolumn{3}{|c|}{$\begin{array}{c}\text { Dešimtadieniai } \\
\text { Decade }\end{array}$} & \multirow{3}{*}{$\begin{array}{c}\text { Per } \\
\text { mėnesil } \\
\text { Per } \\
\text { month }\end{array}$} & \multirow{3}{*}{$\begin{array}{c}1924-2012- \\
2013 \mathrm{~m} . \\
\text { vidurkis } \\
1924-2012- \\
2013 \text { Mean }\end{array}$} \\
\hline & \multicolumn{3}{|c|}{$\begin{array}{c}\text { Dešimtadieniai } \\
\text { Decade }\end{array}$} & \multirow{2}{*}{$\begin{array}{c}\text { Per } \\
\text { ménesi } \\
\text { Permonth }\end{array}$} & & \multirow[t]{2}{*}{ I } & \multirow[t]{2}{*}{ II } & \multirow[t]{2}{*}{ III } & & \\
\hline & $\mathbf{I}$ & II & III & & & & & & & \\
\hline & \multicolumn{10}{|c|}{$2012 \mathrm{~m}}$. \\
\hline Birželis / June & 12,9 & 16,5 & 15,3 & 14,9 & 15,6 & 16,9 & 18,7 & 43,0 & 78,6 & 62,5 \\
\hline Liepa / July & 20,7 & 15,7 & 20,1 & 18,9 & 17,7 & 63,5 & 33,0 & 23,8 & 120,3 & 75,2 \\
\hline Rugpjūtis / August & 18,0 & 16,4 & 15,3 & 16,5 & 16,7 & 43,1 & 3,3 & 35,5 & 81,9 & 74,1 \\
\hline Rugsèjis / September & 14,1 & 13,9 & 11,6 & 13,2 & 12,1 & 7,7 & 24,4 & 10,7 & 42,8 & 51,2 \\
\hline \multirow[t]{2}{*}{ Spalis / October } & 9,8 & 8,4 & 3,6 & 7,2 & 6,8 & 34,7 & 14,5 & 12,4 & 61,6 & 49,9 \\
\hline & \multicolumn{10}{|c|}{$2013 \mathrm{~m}}$. \\
\hline Balandis / April & $-0,8$ & 7,0 & 8,1 & 4,8 & 5,8 & 30,3 & 12,8 & 3,1 & 46,2 & 37,0 \\
\hline Gegužè / May & 14,5 & 17,5 & 16,0 & 16,0 & 12,3 & 0,0 & 19,4 & 30,2 & 49,6 & 52,1 \\
\hline Birželis / June & 19,0 & 16,9 & 19,9 & 18,6 & 15,7 & 16,1 & 1,6 & 28,7 & 46,4 & 62,3 \\
\hline Liepa / July & 19,0 & 17,6 & 18,9 & 18,5 & 17,7 & 2,1 & 56,3 & 45,9 & 104,3 & 75,5 \\
\hline
\end{tabular}

Sejos metais tikètasi, kad ligos bus panašiai išplitę sẻkliniame ir žoliniame pasèliuose, nes žolè nebuvo pjauta, pasèlių priežiūra nesiskyrè, tačiau tiek antraknozè, tiek miltligè sèkliniame pasèlyje išplito intensyviau nei žoliniame. Manome, kad tu- rèjo ịtakos reljefo skirtumai - sèklinis pasèlis pateko į šiek tiek žemesnę vietą, kur susidarè palankesnès sąlygos laikytis drègmei, kartu plisti ligoms.

Miltligè tarp raudonuju dobilu veisliu ir selekcinèse linijose išplito tik sèjos metais (2012). Šios

2 lentelè. Antraknozès, miltligès ir rūdžių pažeistų lapų plotas sezono metu (AUDPC) sèkliniame ir žoliniame raudonųjų dobilų pasèliuose 2012-2013 m.

Table 2. Area under disease progress curve (AUDPC) of anthracnose, mildew and rust in seed and grass red clover crop, 2012-2013

\begin{tabular}{|c|c|c|c|c|c|c|c|c|c|}
\hline \multirow[b]{2}{*}{$\begin{array}{c}\text { Liga } \\
\text { Disease }\end{array}$} & \multirow[b]{2}{*}{$\begin{array}{l}\text { Ploidiškumas } \\
\text { Ploidy }\end{array}$} & \multicolumn{4}{|c|}{ Sèklinis pasèlis / Seed crop } & \multicolumn{4}{|c|}{ Žolinis pasėlis / Grass crop } \\
\hline & & $\begin{array}{l}\text { Vid. } \\
\text { Avg. }\end{array}$ & Se & Min & $\operatorname{Max}$ & $\begin{array}{l}\text { Vid. } \\
\text { Avg. }\end{array}$ & Se & Min & $\operatorname{Max}$ \\
\hline \multicolumn{10}{|c|}{$2012 \mathrm{~m}}$. \\
\hline Antraknozè / Anthracnose & $2 n$ & 182,7 & 12,9 & 63,0 & 367,5 & 155,6 & 10,1 & 63,0 & 367,5 \\
\hline Antraknozè / Anthracnose & $4 n$ & 183,4 & 12,3 & 63,0 & 420,0 & 131,4 & 9,3 & 63,0 & 332,5 \\
\hline Miltligè / Mildew & $2 n$ & 919,0 & 40,3 & 358,0 & 1337,5 & 303,4 & 24,4 & 72,0 & 835,0 \\
\hline Miltligè / Mildew & $4 n$ & 528,9 & 34,7 & 89,5 & 1057,5 & 187,4 & 19,3 & 45,0 & 604,0 \\
\hline \multicolumn{10}{|c|}{$2013 \mathrm{~m}$. } \\
\hline \multicolumn{10}{|c|}{ Iki I pjūties / Before harvest 1} \\
\hline Antraknozè / Anthracnose & $2 n$ & 461,7 & 12,5 & 317,5 & 608,3 & - & - & - & - \\
\hline Antraknozè / Anthracnose & $4 n$ & 405,4 & 12,2 & 258,5 & 553,0 & - & - & - & - \\
\hline Rūdys / Rust & $2 n$ & 929,1 & 43,9 & 264,3 & 1680,0 & 61,1 & 3,5 & 28,7 & 133,0 \\
\hline Rūdys / Rust & $4 n$ & 757,3 & 36,6 & 217,9 & 1165,5 & 35,0 & 4,7 & 5,6 & 77,0 \\
\hline \multicolumn{10}{|c|}{ Iki II pjūties / Before harvest 2} \\
\hline Antraknozė / Anthracnose & $2 n$ & - & - & - & - & 38,2 & 3,1 & 7,7 & 93,3 \\
\hline Antraknozè / Anthracnose & $4 n$ & - & - & - & - & 38,0 & 3,9 & 7,7 & 119 \\
\hline Rūdys / Rust & $2 n$ & - & - & - & - & 32,4 & 2,5 & 7,7 & 205,3 \\
\hline Rūdys / Rust & $4 n$ & - & - & - & & 24,9 & 2,0 & 7,7 & 44,3 \\
\hline
\end{tabular}


ligos pažeistų lapų plotas sezono metu (AUDPC) sèklinio pasèlio diploidiniuose dobiluose buvo vidutiniškai 919,0 (min - 358,0; $\max$ - 1 337,5), o žolinio - vidutiniškai 303,4 (min - 72,0; $\max$ - 835,0). Sèklinio pasèlio tetraploidiniuose dobiluose miltligès vidutinè AUDPC reikšmè siekè 528,9 (min - 89,5; $\max -1057,5)$ o žolinio pasèlio beveik tris kartus mažesnè - 187,4 (min - 45,0; $\max -604,0)$.

Rūdys raudonuosiuose dobiluose išplito tik antraisiais (2013) metais. Žoliniame pasèlyje liga nespèjo smarkiai pažeisti augalų, nes žolè buvo du kartus pjauta. Prieš I pjūtị diploidinių dobilų pažeistų lapų plotas sezono metu (AUDPC) buvo vidutiniškai $61,1(\min -28,7$; $\max -133,0)$, o prieš II pjūtị - vidutiniškai 32,4 (min - 7,7; max - 205,3). Tačiau prieš I pjūti tetraploidiniu dobilų pažeistų lapų plotas sezono metu buvo dvigubai mažesnis - vidutiniškai 35,0 ( $\min$ - 5,6; max - 77,0), o prieš II pjūtị buvo panašus - vidutiniškai 24,9 (min - 7,7; $\max -44,3$ ). Sèkliniame pasèlyje liga galejo plisti iki visiškos augalo brandos. Rūdimis pažeistų lapų plotas sezono metu (AUDPC) diploidinių dobilų sèkliniame pasèlyje buvo vidutiniškai 929,1 (min - 264,3; max - 1680,0$)$, o tetraploidinių dobilų - vidutiniškai 757,3 (min - 217,9; max - 1 165,5). Rūdys ir miltligè labiau pažeidè diploidinių dobilų veisles ir selekcines linijas nei tetraploidinių. E. Arseniuk (1989) nurodo, kad tetraploidiniai dobilai nèra atsparesni miltligei, palyginti su diploidiniais.

Sejos metais (2012) antraknozès požymiai buvo pastebèti tik besibaigiant rugsejjui. Ligos vystymosi intensyvumas buvo lètas. Iki vegeta- cijos pabaigos atliktos tik 2 apskaitos. $2013 \mathrm{~m}$. antraknozès požymiai sèkliniame pasèlyje pasirode birželio 10 d.; atliktos 4 apskaitos. Žoliniame pasèlyje antraknozè pradejo plisti prieš II pjūtị (liepos 15 d.); atliktos 2 apskaitos. Sejos metais antraknozès išplitimas sèkliniame ir žoliniame pasèliuose I apskaitos metu buvo mažas. II apskaitos metu žolinio pasèlio diploidinius dobilus antraknozè pažeidè nuo 6,9 iki $17,0 \%$, o tetraploidinius - nuo 6,5 iki $14,7 \%$ (1 pav.). Sèklinio pasèlio diploidinius dobilus antraknozè pažeidè nuo 7,6 iki $17,8 \%$, o tetraploidinius - nuo 8,0 iki $17,5 \%$.

2013 m. žoliniame pasèlyje antraknozè nespèjo smarkiai išplisti, požymiai buvo pastebèti tik prieš II pjūtį. Sèkliniame pasèlyje liga plito iki visiškos augalo brandos ir smarkiau pažeide pasèli. I apskaitos metu diploidinių raudonųjų dobilų sèkliniame pasèlyje ligos intensyvumas buvo nuo 0,7 iki 1,6 \%, tetraploidiniu - nuo 0,4 iki 0,6\%; II apskaitos metu: diploidinių dobilų - nuo 5,2 iki 6,7 \%, tetraploidinių - nuo 4,0 iki 5,5\% (2 pav.); III apskaitos metu: diploidinių - nuo 11,4 iki 20,8 \%, tetraploidiniu - nuo 9,9 iki 14,2 \%; IV apskaitos metu: diploidiniu - nuo 32,4 iki 51,3\%, tetraploidiniu - nuo 29,3 iki 46,1\%. Kiekvienos apskaitos metu ligos intensyvumas didejo, bet IV apskaitos buvo dvigubai didesnis nei III. Šie duomenys patvirtina kitų autorių teiginius, kad tetraploidiniai dobilai yra atsparesni antraknozei nei diploidiniai (Yamaha, Hasegava, 1990).

2012-2013 m. sèkliniame pasèlyje antraknozei atspariausios diploidinès selekcinès linijos buvo 2 091, 2 106, 2 433, 2088 ir veislès 'Arimaičiai',

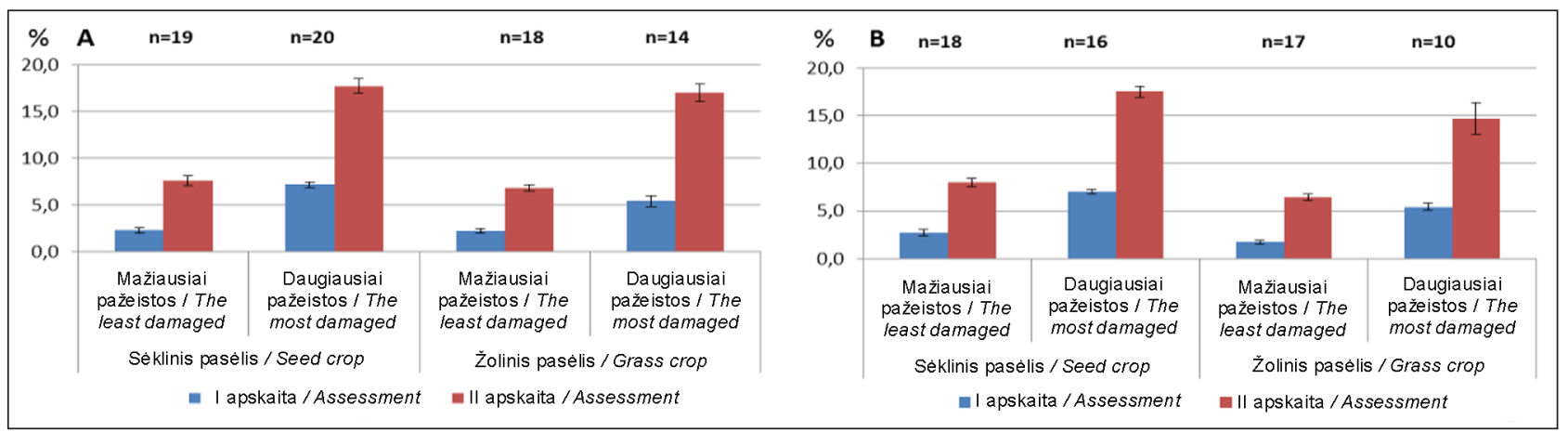

1 pav. Antraknozės intensyvumas diploidinių (A) ir tetraploidinių (B) raudonujjų dobilų sẻkliniame ir žoliniame pasèliuose $2012 \mathrm{~m}$.

Fig. 1. Anthracnose severity in diploid (A) and tetraploid (B) red clover seed and grass crop, 2013 


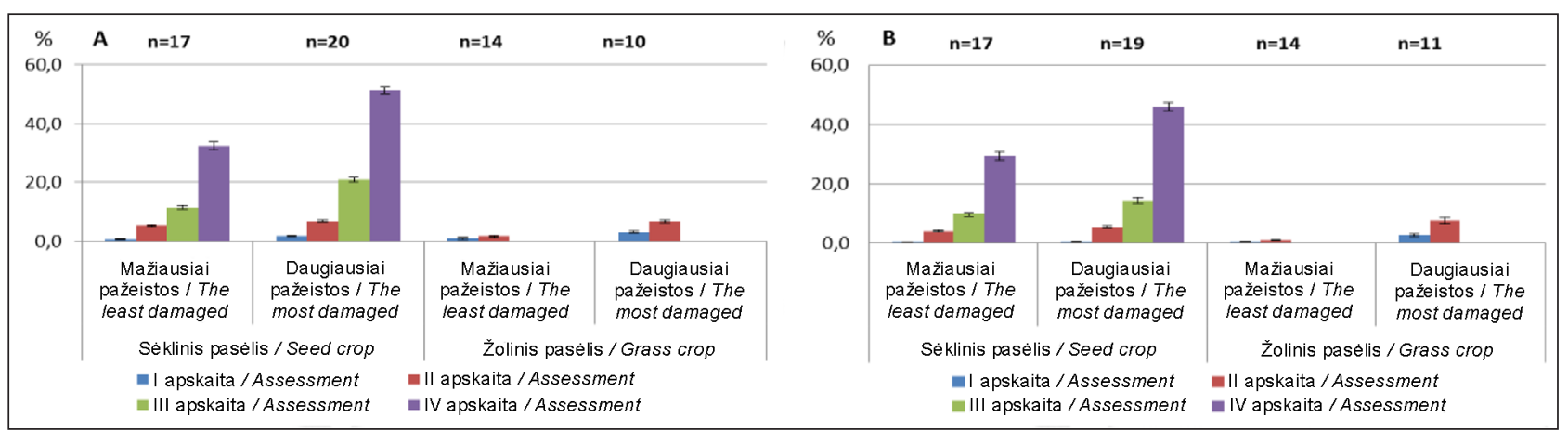

2 pav. Antraknozès intensyvumas diploidinių (A) ir tetraploidinių (B) raudonųjų dobilų sèkliniame ir žoliniame pasèliuose $2013 \mathrm{~m}$.

Fig. 2. Anthracnose severity in diploid (A) and tetraploid (B) red clover seed and grass crop, 2013

'Sandis', 'Radviliai', o tetraploidinès - 2 301, 2 268, 2 281, 2293 ir 'Vulkan', 'Cyklon', 'Divaja', 'Sadūnai' (3 lentelè). Abejais metais tiek sèkliniame, tiek žoliniame pasèlyje atspariausios diploidinès selekcinès linijos buvo 2 091, 2 106, 2 088, o tetraploidinès - 2 281, 2293 ir veislès 'Vulkan', 'Divaja', 'Sadūnai'. Sèkliniame pasèlyje jautriausios antraknozei diploidinès selekcinès linijos 2 093,
2 104, 2 108, 2295 ir veislès 'Sabtoron', 'Nemaro', tetraploidinès - 2302 ir 'Sprint', 'Vyliai', 'Rejista', 'Blizard,' 'Varte'. Tyrimų metais sèkliniame ir žoliniame pasèlyje didžiausiu jautrumu išsiskyre diploidinè selekcinè linija 2093 ir tetraploidinè veislè 'Varte'. Diploidinès ir tetraploidinès selekcinès linijos 2093 ir veislès 'Varte' ligos intensyvumas buvo panašus.

3 lentelè. Mažiausiai ir daugiausiai antraknozès pažeistos raudonųjų dobilų veislès ir selekcinès linijos sẻkliniame ir žoliniame pasẻliuose 2012-2013 m.

Table 3. The most and least damaged by anthracnose red clover varieties and breeding lines in seed and grass crop, 2012-2013

\begin{tabular}{|c|c|c|c|c|c|c|c|c|}
\hline \multirow{3}{*}{$\begin{array}{l}\text { Dobilų veislès, selekcinès linijos } \\
\text { Clover varieties, breeding lines }\end{array}$} & \multicolumn{3}{|c|}{$2012 \mathrm{~m}}$. & \multicolumn{5}{|c|}{$2013 \mathrm{~m}$. } \\
\hline & \multicolumn{2}{|c|}{ Apskaita / Assessment } & \multirow{2}{*}{ AUDPC } & \multicolumn{4}{|c|}{ Apskaita / Assessment } & \multirow{2}{*}{ AUDPC } \\
\hline & I & II & & I & II & III & IV & \\
\hline Sèklinis pasèlis / Seed crop & \multicolumn{8}{|c|}{ Mažiausiai pažeistos $2 \mathrm{n} /$ The least damaged $2 n$} \\
\hline 2091 & 3,7 & 10,0 & 144 & 0,7 & 6,7 & 15,0 & 25,0 & 338 \\
\hline 2106 & 2,3 & 8,3 & 112 & 0,4 & 3,7 & 8,3 & 33,3 & 351 \\
\hline 'Arimaičiai' & 1,0 & 5,0 & 63 & 0,7 & 5,0 & 10,0 & 33,3 & 376 \\
\hline 'Sandis' & 1,0 & 5,0 & 63 & 0,1 & 5,0 & 15,0 & 33,3 & 376 \\
\hline 'Radviliai' & 2,3 & 6,7 & 95 & 0,7 & 5,0 & 10,0 & 33,3 & 377 \\
\hline 2433 & 3,7 & 10,0 & 144 & 1,0 & 5,0 & 15,0 & 33,3 & 379 \\
\hline 2088 & 2,3 & 6,7 & 95 & 0,4 & 5,0 & 10,0 & 33,3 & 379 \\
\hline \multicolumn{9}{|l|}{ Žolinis pasèlis / Grass crop } \\
\hline 2270 & 1,0 & 5,0 & 63 & 0,4 & 1,0 & - & - & 10 \\
\hline 'Van' & 2,3 & 6,7 & 95 & 0,4 & 1,0 & - & - & 10 \\
\hline 2088 & 1,0 & 5,0 & 63 & 0,7 & 1,0 & - & - & 12 \\
\hline 'Britta' & 2,3 & 8,3 & 112 & 0,7 & 1,0 & - & - & 12 \\
\hline 2087 & 1,0 & 5,0 & 63 & 1,0 & 2,3 & - & - & 23 \\
\hline 2091 & 2,3 & 8,3 & 112 & 1,0 & 6,7 & - & - & 54 \\
\hline 2106 & 3,7 & 8,3 & 126 & 3,7 & 8,3 & - & - & 84 \\
\hline
\end{tabular}


3 lentelè (tęsinys)

Table 3 (continued)

Sèklinis pasèlis / Seed crop

Mažiausiai pažeistos $4 \mathrm{n} /$ The least damaged $4 n$

\begin{tabular}{ccccccccc}
\hline 2301 & 1 & 6,7 & $\mathbf{8 1}$ & 0,1 & 3,7 & 8,3 & 20,0 & $\mathbf{2 5 9}$ \\
\hline 2268 & 3,7 & 8,3 & $\mathbf{1 2 6}$ & 0,1 & 5,0 & 10,0 & 33,3 & $\mathbf{3 7 7}$ \\
\hline 2281 & 5 & 10 & $\mathbf{1 5 8}$ & 0,7 & 3,7 & 13,3 & 33,3 & $\mathbf{3 5 2}$ \\
\hline 2293 & 3,7 & 10 & $\mathbf{1 4 4}$ & 0,7 & 5,0 & 10,0 & 33,3 & $\mathbf{3 7 0}$ \\
\hline 2300 & 3,7 & 10 & $\mathbf{1 4 4}$ & 0,7 & 5,0 & 10,0 & 33,3 & $\mathbf{3 6 8}$ \\
\hline 'Vulkan' & 1 & 5 & $\mathbf{6 3}$ & 0,7 & 5,0 & 10,0 & 33,3 & $\mathbf{3 7 8}$ \\
\hline 'Cyklon' & 5 & 10 & $\mathbf{1 5 8}$ & 1,0 & 3,7 & 10,0 & 25,0 & $\mathbf{2 9 7}$ \\
\hline 'Divaja' & 1 & 6,7 & $\mathbf{8 1}$ & 0,4 & 3,7 & 10,0 & 25,0 & $\mathbf{2 9 5}$ \\
\hline 'Sadūnai' & 3,7 & 10 & $\mathbf{1 4 4}$ & 0,7 & 5,0 & 10,0 & 33,3 & $\mathbf{3 7 6}$ \\
\hline
\end{tabular}

Žolinis pasèlis / Grass crop

\begin{tabular}{ccccccccc}
\hline 'Vulkan' & 1,0 & 5,0 & $\mathbf{6 3}$ & 0,4 & 1,0 & - & - & $\mathbf{1 0}$ \\
\hline 'Divaja' & 1,0 & 5,0 & $\mathbf{6 3}$ & 1,0 & 3,7 & - & - & $\mathbf{3 3}$ \\
\hline 2301 & 1,0 & 5,0 & $\mathbf{6 3}$ & 1,0 & 3,7 & - & - & $\mathbf{3 3}$ \\
\hline 2274 & 1,0 & 5,0 & $\mathbf{6 3}$ & 1,0 & 1,0 & - & - & $\mathbf{1 4}$ \\
\hline 'Amos' & 2,3 & 6,7 & $\mathbf{9 5}$ & 0,1 & 1,0 & - & - & $\mathbf{8}$ \\
\hline 2293 & 2,3 & 6,7 & $\mathbf{9 5}$ & 2,3 & 3,7 & - & - & $\mathbf{4 2}$ \\
\hline 'Rejista' & 2,3 & 8,3 & $\mathbf{1 1 2}$ & 0,7 & 1,0 & - & - & $\mathbf{1 2}$ \\
\hline 2281 & 2,3 & 8,3 & $\mathbf{1 1 2}$ & 2,3 & 3,7 & - & - & $\mathbf{4 2}$ \\
\hline 'Sadūnai' & 3,7 & 10,0 & $\mathbf{1 4 4}$ & 1,7 & 1,0 & - & - & $\mathbf{1 9}$ \\
\hline
\end{tabular}

Sèklinis pasèlis / Seed crop

Daugiausiai pažeistos $2 \mathrm{n} /$ The most damaged $2 n$

\begin{tabular}{|ccccccccc}
2093 & 5,3 & 15,0 & $\mathbf{2 1 4}$ & 1,0 & 6,7 & 15,0 & 50,0 & $\mathbf{5 2 9}$ \\
\hline 2104 & 6,7 & 15,0 & $\mathbf{2 2 8}$ & 1,0 & 5,0 & 15,0 & 50,0 & $\mathbf{5 0 1}$ \\
\hline 2108 & 6,7 & 15,0 & $\mathbf{2 2 8}$ & 2,3 & 8,3 & 25,0 & 58,3 & $\mathbf{6 0 7}$ \\
\hline 2295 & 6,7 & 15,0 & $\mathbf{2 2 8}$ & 1,0 & 8,3 & 25,0 & 58,3 & $\mathbf{6 0 8}$ \\
\hline 'Sabtoron' & 6,7 & 15,0 & $\mathbf{2 2 8}$ & 1,0 & 5,0 & 20,0 & 50,0 & $\mathbf{5 1 2}$ \\
\hline 'Nemaro' & 6,7 & 15,0 & $\mathbf{2 2 8}$ & 1,0 & 6,7 & 20,0 & 41,7 & $\mathbf{4 9 5}$ \\
\hline
\end{tabular}

Žolinis pasèlis / Grass crop

\begin{tabular}{|c|c|c|c|c|c|c|c|c|}
\hline 2177 & 3,7 & 13,3 & 179 & 2,3 & 5,0 & - & - & 51 \\
\hline 2331 & 6,7 & 15,0 & 228 & 2,3 & 5,0 & - & - & 51 \\
\hline 'Astra' & 5,0 & 15,0 & 210 & 3,7 & 6,7 & - & - & 72 \\
\hline 2093 & 8,3 & 20,0 & 298 & 1,0 & 5,0 & - & - & 42 \\
\hline Sèklinis pasèlis / Seed crop & \multicolumn{8}{|c|}{ Daugiausiai pažeistos $4 \mathrm{n} /$ The most damaged $4 n$} \\
\hline 'Sprint' & 6,7 & 15,0 & 228 & 0,7 & 5,0 & 10,0 & 41,7 & 436 \\
\hline 'Vyliai' & 7,0 & 18,3 & 266 & 1,0 & 5,0 & 10,0 & 41,7 & 433 \\
\hline 'Rejista' & 5,3 & 18,3 & 249 & 1,0 & 8,3 & 15,0 & 50,0 & 540 \\
\hline Blizard' & 8,4 & 20,4 & 302 & 0,7 & 5,0 & 10,0 & 41,7 & 430 \\
\hline 'Varte' & 6,7 & 15,0 & 228 & 0,7 & 3,7 & 8,3 & 58,3 & 521 \\
\hline 2302 & 6,7 & 15,0 & 228 & 0,4 & 5,0 & 10,0 & 41,7 & 430 \\
\hline \multicolumn{9}{|l|}{ Žolinis pasėlis / Grass crop } \\
\hline 'Nodula & 5,0 & 10,0 & 158 & 0,1 & 9,0 & - & - & 64 \\
\hline 2282 & 4,0 & 11,7 & 165 & 2,3 & 6,7 & - & - & 63 \\
\hline 2298 & 5,0 & 10,0 & 158 & 5,0 & 7,0 & - & - & 84 \\
\hline 'Varte' & 5,0 & 10,0 & 158 & 2,3 & 5,0 & - & - & 51 \\
\hline 'Beskyd' & 6,7 & 25,0 & 333 & 0,1 & 17,0 & - & - & 120 \\
\hline
\end{tabular}


I apskaitos metu (rugsèjo 10 d.) sèkliniame ir žoliniame pasèlyje diploidinių ir tetraploidinių dobilų miltligès pažeidimai buvo neženklūs. Lètam ligos plitimui itakos galejo turèti meteorologinès sąlygos, nes rugsèjis buvo šiltas, vèjuotas, o lietūs nebuvo gausūs. II apskaitos metu (rugsèjo 28 d.) miltligès pažeidimai jau didesni.

Diploidinių raudonųjų dobilų sèkliniame pasèlyje miltligès intensyvumas buvo nuo 13,1 iki 28,0 \%, o tetraploidinių - nuo 7,1 iki 18 \% (3 pav.). Žolinio pasèlio diploidinius dobilus miltligè pažeidè nuo 3,3 iki 8,1 \%, o tetraploidinius - nuo 1,5 iki $6 \%$ (3 pav.). III apskaitos metu, spalio 19 d., ligos pažeidimai buvo intensyvesni net du kartus. Diploidinių dobilų sẻkliniame pasėlyje miltligès ligos intensyvumas siekè 29,4-52,2 \%, tetraploidinių - 17,2-37,4\%. Žolinio pasèlio diploidinius dobilus miltligè pažeidè nuo 10,1 iki $26,7 \%$, o tetraploidinius - nuo 5,8 iki
$17,4 \%$. Sèkliniame ir žoliniame pasèliuose diploidiniai dobilai buvo labiau pažeisti nei tetraploidiniai. Žolinio pasèlio raudonieji dobilai I-III apskaitos metu buvo atsparesni už sèklinio pasèlio dobilus.

Rūdžių požymiai raudonuosiuose dobiluose pastebèti gegužès pabaigoje. Sèkliniame pasèlyje iki visiškos augalo brandos atliktos 5 apskaitos, o žoliniame pasèlyje - 2 apskaitos prieš I pjūtị ir 2 apskaitos prieš II pjūtį. Žoliniame pasèlyje rūdžių išplitimas buvo labai mažas (tiek prieš I, tiek ir prieš II pjūtį). I apskaitos metu (gegužès $27 \mathrm{~d}$.) sèkliniame pasèlyje rūdžių pažeidimai buvo nedideli.

II apskaitos metu (birželio 10 d.) rūdžių intensyvumas diploidinių raudonųjų dobilų pasèliuose buvo 3,5-5,9\%, o tetraploidinių - 1,4-3,0 \% (4 pav.); III apskaitos metu (birželio 24 d.): diploidinių - 7,8$13,1 \%$, tetraploidiniu - 6,9-11,7 \%; IV apskaitos metu (liepos 8 d.): diploidinių - 15,5-35,5 \%,

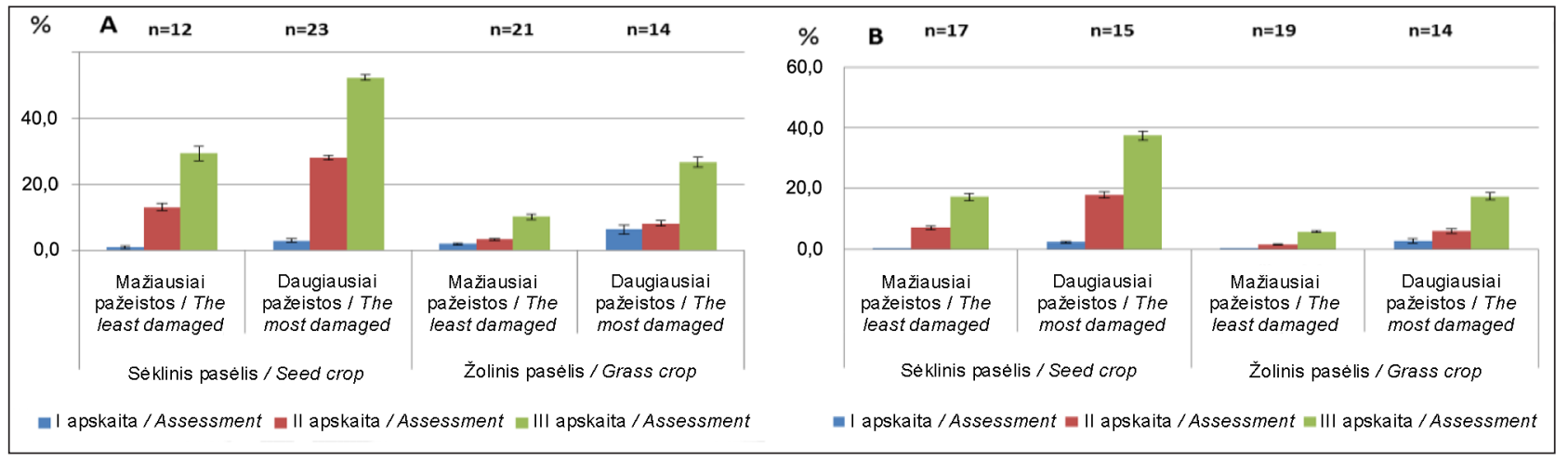

3 pav. Miltligès intensyvumas diploidinių (A) ir tetraploidinių (B) raudonujų dobilų sèkliniame ir žoliniame pasèliuose $2012 \mathrm{~m}$.

Fig. 3. Mildew severity in diploid (A) and tetraploid (B) red clover seed and grass crop, 2012

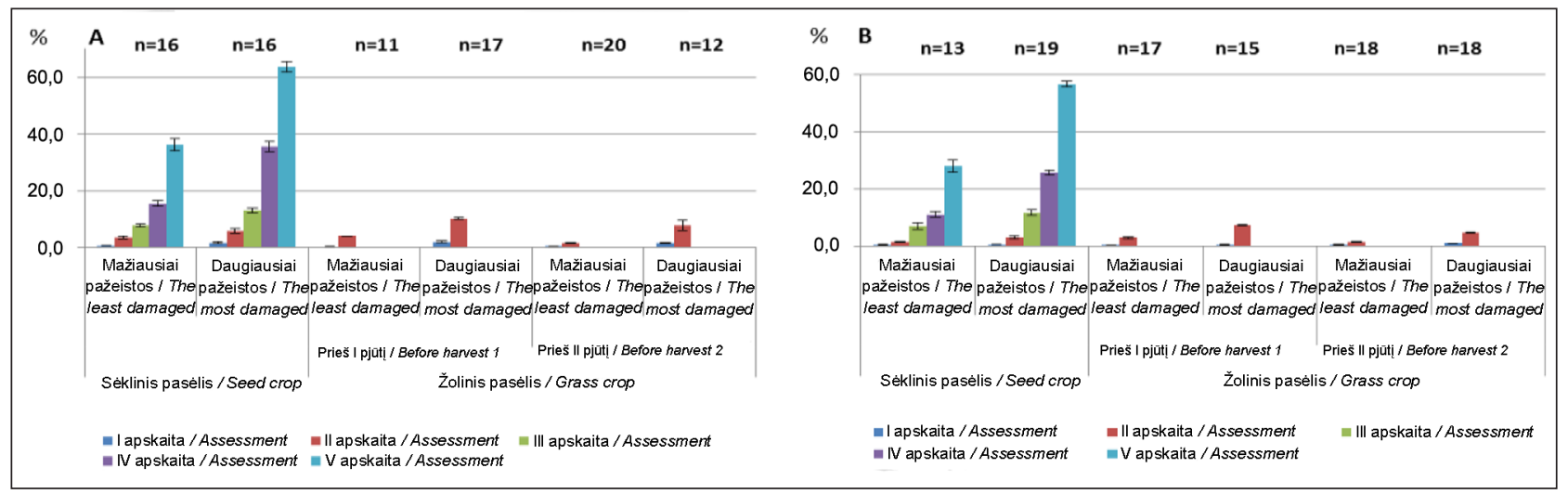

4 pav. Rūdžių intensyvumas diploidinių (A) ir tetraploidinių (B) raudonųjų dobilų sèkliniame ir žoliniame pasèliuose $2013 \mathrm{~m}$.

Fig. 4. Rust severity in diploid (A) and tetraploid (B) red clover seed and grass crop, 2013 
tetraploidinių - 11,0-25,6 \%; V apskaitos metu (liepos 22 d.): diploidinių - 36,3-63,5\%, tetraploidinių - 27,9-56,6 \%.

$2012 \mathrm{~m}$. antraknozè diploidinius ir tetraploidinius raudonuosius dobilus pažeidè panašiai (4 lentelè). $2013 \mathrm{~m}$. antraknozè sèklinio pasèlio diploidinius dobilus pažeidè smarkiau, palyginti su tetraploidiniais, bet žoliniame pasèlyje diploidiniai ir tetraploidiniai dobilai buvo pažeisti vienodai. Sèkliniame pasèlyje liga plito iki visiškos augalo brandos, o žoliniame pasèlyje liga nespèjo išplisti, nes buvo pjaunama žolè (tikètina, tai turejo ịtakos ligos plitimui ir pasiskirstymui). Miltligè ir rūdys abiejuose pasèliuose labiau pažeidè diploidinius nei tetraploidinius dobilus.

\section{IŠVADOS}

1. Tirtos raudonųjų dobilų selekcinès linijos ir veislès ženkliai skyrèsi pagal atsparumą miltligei, antraknozei ir rūdims.

2. $2013 \mathrm{~m}$. sèkliniame pasèlyje antraknozei iš esmès buvo atsparesni tetraploidiniai dobilai.

3. 2012-2013 m. sèkliniuose ir žoliniuose raudonųjų dobilų pasèliuose antraknozei atspariausios buvo diploidinès selekcinès linijos 2 091, 2 106, 2 088, tetraploidinès - 2281, 2293 ir veislès 'Vulkan', 'Divaja', 'Sadūnai'; jautriausios - diploidinè selekcinè linija 2093 ir tetraploidinè veislè 'Varte'.

4. Miltligè ir rūdys dobiluose ženkliai išplito tik susidarius palankioms oro sąlygoms: miltligè -

4 lentelè. Diploidinių ir tetraploidinių raudonųjų dobilų atsparumas miltligei, antraknozei ir rūdims 2012$2013 \mathrm{~m}$.

Table 4. Resistance of diploid and tetraploid red clover to mildew, anthracnose and rust, 2012-2013

\begin{tabular}{|c|c|c|c|c|c|c|c|}
\hline \multirow{2}{*}{$\begin{array}{l}\text { Sèklinis ir žolinis pasẻlis } \\
\text { Seed and grass crop }\end{array}$} & \multicolumn{5}{|c|}{ Apskaita / Assessment } & \multirow{2}{*}{$\begin{array}{l}\text { Vid. } \\
\text { Average }\end{array}$} & \multirow{2}{*}{ AUDPC } \\
\hline & $\mathbf{I}$ & II & III & IV & $\mathbf{V}$ & & \\
\hline & \multicolumn{7}{|c|}{ Miltligè 2012 m. / Mildew 2012} \\
\hline $2 n$ & $2,83 a$ & $12,88 \mathrm{a}$ & $28,55 \mathrm{a}$ & - & - & $14,76 \mathrm{a}$ & $590 a$ \\
\hline $4 n$ & $1,04 \mathrm{~b}$ & $8,42 \mathrm{~b}$ & $20,03 b$ & - & - & $9,86 \mathrm{~b}$ & $427 b$ \\
\hline \multirow[t]{2}{*}{$\mathrm{R}_{05} / L S D$} & 0,678 & 1,837 & 3,122 & - & - & 1,721 & 112,0 \\
\hline & \multicolumn{7}{|c|}{ Antraknozè 2012 m. / Anthracnose 2012} \\
\hline $2 \mathrm{n}$ & $4,38 \mathrm{a}$ & $11,42 \mathrm{a}$ & - & - & - & $7,90 \mathrm{a}$ & $134 \mathrm{a}$ \\
\hline $4 \mathrm{n}$ & $3,94 \mathrm{a}$ & $11,05 \mathrm{a}$ & - & - & - & $7,5 \mathrm{a}$ & $117 \mathrm{a}$ \\
\hline $\mathrm{R}_{05} / L S D$ & 0,524 & 1,209 & - & - & - & 0,835 & 21,1 \\
\hline Sëklinis pasèlis / Seed crop & \multicolumn{7}{|c|}{ Antraknozè 2013 m. / Anthracnose 2013} \\
\hline $2 \mathrm{n}$ & $1,16 \mathrm{a}$ & $6,01 \mathrm{a}$ & $16,82 \mathrm{a}$ & $42,44 \mathrm{a}$ & - & $16,64 \mathrm{a}$ & $462 \mathrm{a}$ \\
\hline $4 \mathrm{n}$ & $0,510 \mathrm{~b}$ & $4,80 \mathrm{~b}$ & $12,32 \mathrm{~b}$ & $38,17 \mathrm{~b}$ & - & $13,94 b$ & $405 b$ \\
\hline $\mathrm{R}_{05} / L S D$ & 0,237 & 0,544 & 1,706 & 3,998 & - & 1,402 & 35,4 \\
\hline & \multicolumn{7}{|c|}{ Rūdys 2013 m. / Rust 2013} \\
\hline $2 \mathrm{n}$ & $1,12 \mathrm{a}$ & $2,44 \mathrm{a}$ & $10,3 \mathrm{a} 6$ & $25,44 a$ & $50,89 a$ & $18,47 a$ & $929 a$ \\
\hline $4 n$ & $0,46 b$ & $4,57 \mathrm{~b}$ & $9,76 b$ & $19,67 \mathrm{~b}$ & $43,98 \mathrm{~b}$ & $15,25 b$ & $757 b$ \\
\hline $\mathrm{R}_{05} / L S D$ & 0,245 & 0,711 & 1,396 & 2,810 & 4,461 & 1,611 & 115,8 \\
\hline $\begin{array}{l}\text { Žolinis pasèlis prieš II pjūtị } \\
\text { Grass crop before harvest } 2\end{array}$ & \multicolumn{7}{|c|}{ Antraknozè 2013 m. / Anthracnose 2013} \\
\hline $2 \mathrm{n}$ & $1,48 \mathrm{a}$ & $3,98 \mathrm{a}$ & - & - & - & $2,73 a$ & $38 \mathrm{a}$ \\
\hline $4 \mathrm{n}$ & $1,47 \mathrm{a}$ & $3,97 a$ & - & - & - & $2,71 \mathrm{a}$ & $38 \mathrm{a}$ \\
\hline $\mathrm{R}_{05} / L S D$ & 0,397 & 0,868 & - & - & - & 0,518 & 10,1 \\
\hline Prieš I pjūti / Before harvest 1 & \multicolumn{7}{|c|}{ Rūdys 2013 m. / Rust 2013} \\
\hline $2 \mathrm{n}$ & $1,08 \mathrm{a}$ & $7,65 \mathrm{a}$ & - & - & - & $4,38 \mathrm{a}$ & $61 \mathrm{a}$ \\
\hline $4 n$ & $0,28 \mathrm{~b}$ & $4,72 b$ & - & - & - & $2,54 \mathrm{~b}$ & $35 b$ \\
\hline $\mathrm{R}_{05} / L S D$ & 0,365 & 1,13 & - & - & - & 0,658 & 8,9 \\
\hline Prieš II pjūtị / Before harvest 2 & \multicolumn{7}{|c|}{ Rūdys 2013 m. / Rust 2013} \\
\hline $2 \mathrm{n}$ & $0,79 \mathrm{a}$ & $3,85 \mathrm{a}$ & - & - & - & $2,34 \mathrm{a}$ & $32 \mathrm{a}$ \\
\hline $4 n$ & $0,67 b$ & $2,89 \mathrm{a}$ & - & - & - & $1,80 \mathrm{a}$ & $25 \mathrm{a}$ \\
\hline $\mathrm{R}_{05} / L S D$ & 0,172 & 1,257 & - & - & - & 0,656 & 10,6 \\
\hline
\end{tabular}


2012 m., rūdys - 2013 m. Abi ligos labiau pažeidè diploidinius raudonuosius dobilus nei tetraploidinius.

5. Sèkliniuose pasèliuose antraknozė, miltligè ir rūdys išplito intensyviau nei žoliniuose, kur buvo pjaunama žolè.

Gauta 20140318

Priimta 20140626

\section{LITERATŪRA}

1. Anonymous author. 2003. Kentucky Pest News. No. 981. 1 p. [cited 2014-01-15]. Available from: http://www.uky.edu/Agriculture/kpn/kpnhome. htm

2. Arseniuk E. 1989. Effect of the polyploidization red clover (Trifolium pranese L.) on winter hardiness and resistance to some diseases. Hodowla roslin, Aklimatizacja Nasienitstwo. Vol. 33. P. 1-30.

3. Bayliss K. L., Kuo J., Sivastthamparam K., Barbenti M. J., Lagudah E. S. 2002. Differences in symptom development in subterranean clover infected with Kabatiella caulivora Race 1 and Race 2 are related to host resistance. Australian Journal for Agricultural Research. Vol. 53. P. 305-310.

4. Bayliss K. L., Kuo J., Sivastthamparam K., Barbenti M. J., Lagudah E. S. 2001. Infection of Subterranean clover (Trifolium suterraneum) by Kabatiell caulivora. Journal of Phytopatology. Vol. 149. P. 699-705.

5. Boller B., Schubiger F., Kölliker R., ReckenholzTänikon A. 2010. Fodder Crops and Amenity Grasses. 523 p.

6. Campbell C. L., Madden L. V. 1990. Introduction to Plant Disease Epidemiology. New York. 530 p.

7. Gaue R., Ingwerasen B. 2003. Methods and results of red clover breeding at the Norddeutsche Pfalnzenzucht Hans-Georg Lembke KG. Czech Journal of Plant Breeding. Vol. 36 (Spec. Iss.). P. 8690.

8. Gaurilčikienè I. 1992. Kabatiella caulivora (Kirchn.) Karak. biologijos ypatumas ir jam atspariu raudonuju dobilu veisliu atranka. Biologijos mokslų kandidato disertacija. Dotnuva. $132 \mathrm{p}$.

9. Gaurilčikienė I., Staniulis J. 2006. Daugiamečiu žolių ligos. Lauko augalu ligos ir kenkèjai. Lietuvos žemdirbystès institutas. $275 \mathrm{p}$.

10. Hartleb H., Heitefuss R., Hoppe H. H. 1997. Resistance of Crop Plants against Fungi. Stuttgart: Gustav Fisher Verlag. 543 p.

11. Hartung K., Piepho H. 2007. Are ordinary rating scales better than percent ratings? A statistical and "psychological" view. Euphytica. Vol. 155. P. 15-26.

12. Hua L., Nichols P. G. H., Han S., Fostewr K. J., Sivasitthamparam K., Barbetti M. J. 2009. Resistance to race 2 and cross-ressitance to race 1 of Kabatiella caulivora in Trifolium subterraneum and T. purpureum. Australasian Plant Pathology. Vol. 38. P. 284-287.

13. Inch J. J., Irwin I. A. G., Gray R. A. 1993. Seasonal variation in Lucerne foliar disease and cultivar reaction to leaf spot pathogens in the field in southern Queensland. Australian Journal of Experimental Agriculture. Vol. 33. P. 343-348.

14. Yamaha M., Hasegava T. 1990. New forage crop varieties registered by the Ministry of Agriculture, Forestry and Fisheries in 1989 and 1990. Japanese Journal of Breeding. Vol. 40. P. 549-554.

15. Janossy A. 1971. A Vicia-fajok termesztese es nemesitese (Bukkonytermesztes). Budapest: Akademiai Kiado. 247 p.

16. Liatukas Ž., Bukauskaitè J. 2012. Differences in yielding capability of diploid and tetraploid red clover in Lithuania. Proceedings of the Latvian Academy of Sciences. Section B, Vol. 66. No. 4(5). P. 153-163.

17. Meier U. 2001. Growth stages of mono-and dicotyledonous plants. BBCH Monograph. P. 94-98.

18. Öhberg H., Ruth P., Bang U. 2005. Effect of ploidy and flowering type of red clover cultivars and isolate origin on severity of clover rot (Sclerotinia trifoliorum). Phytopathology. Vol. 153. P. 505-511.

19. Okumura K. 2005. Research strategies for forage legume breeding in Japan. Vestnik VOGiS. Vol. 9. P. 423-429.

20. Onberg H., Ruth P., Bang U. 2008. Differential responses of red clover cultivars to Sclerotinia trifoliorum under diverse natural climatic conditions. Plant Pathology. Vol. 57. No. 3. P. 459-466.

21. Pokorny R., Anderson V., Nedelnik J., Riha P. 2003. Current state of red clover breeding for resistance in Central and Northern Europe. Czech Journal of Plant Breeding. Vol. 36 (Spec. Iss.). P. 82-85.

22. Poland J. A., Nelson R. J. 2011. In the eye of the beholder: the effect of rater variability and different rating scales on QTL mapping. Phytopathology. Vol. 101. P. 290-298.

23. Repšienè R., Skuodienè R. 2006. Resistance of red clover to diseases and pests under different growing conditions. Agronomy Research. Vol. 4. P. 327330.

24. Rizvi S. S. A., Nutter F. W., Jr. 1993. Seasonal dynamics of alfalfa foliar pathogens in Iowa. Plant Disease. Vol. 77. P. 1126-1135.

25. Smith R. R., Manim P., Grau C. R., Sharpee D. K. 1993. Reaction of Red Clover to Ascos-pore Inoculum of Sclerotinia trifoliorum. Agros Abstract. $102 \mathrm{p}$.

26. Svirskis A. 1995. Yield Increasing of Herbage Legume Species by Plant Breeding. The Work of Doctor Habilitatus. $154 \mathrm{p}$.

27. Taylor N. L. 2008. A century of clover breeding developments in the United States. Crop Science. Vol. 48. P. 1-13.

28. Taylor N. L. 1996. Red Clover Science. Dordrecht, the Netherlands: Kluwer Academic Publishers. 
29. Tarakanovas P., Raudonius S. 2003. Agronominiu tyrimu duomenu statistine analize taikant kompiuterines programas ANOVA, STAT, SPULIT-PLOT iš paketo SELEKCIJA ir IRRISTAT. Akademija, $58 \mathrm{p}$.

30. Xie C., Xu S., Mosjidis J. A. 1997. Multistage selection indices for maximum genetic gain and economic efficiency in red clover. Euphytica. Vol. 98. P. 75-82.

Jovita Bukauskaitė, Skaidrė Supronienė, Nijolè Lemežienė, Vida Danytè

RESISTANCE OF DIPLOID AND TETRAPLOID RED CLOVER (TRIFOLIUM PRATENSE L.) TO MILDEW (ERYSIPHE TRIFOLII), ANTHRACNOSE (KABATIELLA CAULIVORA) AND RUST (UROMYCES TRIFOLII)

\section{Sum $m$ ary}

The investigations of red clover resistance to mildew (Erysphe trifolii), anthracnose (Kabatiella caulivora) and rust (Uromyces trifolii) were carried out at the Institute of Agriculture, Lithuanian Research Centre for Agriculture and For- estry. 84 varieties of different origin, breeding lines and wild or semi-wild ecotypes were investigated at field conditions with natural infection of mildew (E. trifolii), anthracnose (K. caulivora), and rust (U. trifolii). The results of the investigation show that the diploid lines 2 091, 2 106, 2088 and tetraploid lines 2 281, 2293 and the tetraploid varieties 'Vulkan,' 'Divaja,' 'Sadūnai' were the most resistant to anthracnose. The diploid variety 2093 and tetraploid variety 'Varte' were the most susceptible to anthracnose. Mildew prevailed only in 2012 and rust prevailed in 2013. Diploid red clover was more susceptible to mildew and rust compared to tertraploid. The diseases incidence in grass crop was low because of grass cutting. But in seed crop the diseases incidence was intensive till the full maturity and the diseases severity was high.

The aim of the investigation was to evaluate the resistance of the diploid and tetraploid red clover (Trifolium pratense) genetic collection to anthracnose (Kabatiella caulivora (Kirchn.) Karak.), mildew (Erysiphe trifolii), and rust (Uromyces trifolii).

Key words: Trifolium pratense, Erysiphe, Kabatiela caulivora, Uromyces trifolli, resistance 